\title{
PENGARUH WORD OF MOUTH TERHADAP KEPERCAYAAN KONSUMEN DALAM BERBELANJA SECARA ONLINE
}

\section{Kartika Imasari Tjiptodjojo ${ }^{1}$, Surya Setyawan ${ }^{2}$, Henky Lisan Suwarno ${ }^{3}$, Yolla Margaretha $^{4}$}

\author{
${ }^{1}$ Program Sarjana Manajemen, Universitas Kristen Maranatha \\ Email: kartika.it@eco.maranatha.edu \\ ${ }^{2}$ Program Sarjana Manajemen, Universitas Kristen Maranatha \\ Email: surya.setyawan@eco.maranatha.edu \\ ${ }^{3}$ Program Sarjana Manajemen, Universitas Kristen Maranatha \\ Email: henky.ls@eco.maranatha.edu \\ ${ }^{4}$ Program Sarjana Manajemen, Universitas Kristen Maranatha \\ Email: yolla.margaretha@eco.maranatha.edu
}

\begin{abstract}
This study wants to describe the marketing communication strategy widely used today, namely word of mouth where this form of communication purely relies on the ability of consumers to hear and convey messages or news through conversation. Through word of mouth, consumers can feel a more personal relationship with the company. The word-of-mouth communication strategy is considered quite capable in building consumer confidence in shopping, especially shopping online. This research took a sample of 100 respondents in Bandung City who actively visit the marketplace and make purchases at least twice a month. The results showed that there was an effect of word of mouth on consumer confidence of 0.263 or 26.3 percent.
\end{abstract}

Keywords: word of mouth; marketing communication; trust.

\begin{abstract}
ABSTRAK
Penelitian ini ingin menggambarkan mengenai strategi komunikasi pemasaran banyak digunakan pada masa sekarang yaitu word of mouth dimana bentuk komunikasi ini secara murni mengandalkan kemampuan konsumen dalam mendengar dan menyampaikan pesan atau berita melalui percakapan. Melalui word of mouth, konsumen dapat merasakan hubungan yang lebih pribadi dengan perusahaan. Strategi komunikasi word of mouth dinilai cukup mampu membangun kepercayaan konsumen dalam berbelanja, khususnya belanja online. Penelitian ini mengambil sampel 100 responden masyarakat di Kota Bandung yang secara aktif mengunjungi marketplace dan melakukan pembelian minimal dua kali dalam sebulan. Hasil penelitian menunjukkan bahwa terdapat pengaruh word of mouth terhadap kepercayaan konsumen sebesar 0,263 atau 26,3 persen.
\end{abstract}

Kata Kunci: word of mouth; komunikasi pemasaran; kepercayaan.

\section{PENDAHULUAN}

\section{Latar Belakang}

Perkembangan komunikasi saat ini telah menghantarkan berbagai perilaku dalam masyarakat. Secara tradisional proses komunikasi adalah mengirimkan pesan hingga tersampaikannya pesan melalui berbagai media. Penggunaan media yang tepat akan memengaruhi tingkat keberhasilan dalam penyampaian pesan. Keberhasilan penyampaian pesan akan mendorong terciptanya komunikasi yang akan mendorong hasil atau output yang baik. Sebagian besar masyarakat mulai menyadari bahwa salah satu faktor keberhasilan dalam hidup adalah kemampuan beradaptasi melalui komunikasi dengan lingkungan. Oleh karena itu kemampuan komunikasi harus dapat ditingkatkan seiring dengan semakin berkembangnya lingkungan.

Bentuk komunikasi yang saat ini banyak memengaruhi lingkungan pemasaran adalah word of mouth, dimana bentuk komunikasi ini secara murni mengandalkan kemampuan konsumen dalam mendengar dan menyampaikan pesan atau berita melalui percakapan. Melalui word of mouth, konsumen dapat merasakan hubungan yang lebih pribadi dengan perusahaan. (Kotler dan Keller, 2013). Hal tersebut dapat mendorong dan memaksa perusahaan untuk lebih dalam mempelajari mengenai preferensi dan tingkah laku konsumen. Word of mouth juga dianggap sebagai salah 
satu bentuk strategi pemasaran yang cukup menarik karena tidak memerlukan pembiayaan yang cukup besar, tetapi mampu memberikan efektivitas yang sangat besar (Toruan, 2018). Rantai komunikasi yang tidak terputus serta pemasaran berbiaya murah bahkan gratis dapat menjadikan word of mouth sebagai strategi komunikasi pemasaran yang banyak digunakan pada masa sekarang, mengingat semakin maju teknologi yang juga akan semakin memudahkan untuk tersampaikan dan tersimpannya berbagai bentuk pesan melalui offline dan online. Rantai pesan yang tersampaikan akan memengaruhi tingkat affect, behavior, cognition (ABC) dari konsumen. (Peter dan Olson, 2010). Affect, behavior, cognition (ABC) merupakan bentuk respon konsumen atas rangsangan yang muncul dari lingkungan. Respon yang muncul dapat berupa perasaan, pengetahuan maupun perilaku, salah satunya adalah dengan terbentuknya kepuasan konsumen. (Giese dan Cote, 2002). Kepuasan konsumen yang tercipta setelah pengalaman berbelanja atau mengkonsumsi produk atau jasa akan membentuk kepercayaan konsumen. (Norhermaya dan Soesanto, 2016).

Membangun kepercayaan konsumen merupakan salah satu tantangan terberat dalam pemasaran. Kepercayaan akan tumbuh jika pemasar mampu memberikan yang terbaik serta menurunkan tingkat risiko di mata konsumen. Jika konsumen telah memilih untuk mempercayai sebuah produk atau merek, akan mudah bagi konsumen untuk memutuskan penggunaan dari produk atau merek tersebut. Jadi dengan kata lain keinginan untuk berperilaku dalam pembelian merupakan salah satu konsekuensi dari dibangunnya sebuah kepercayaan. (Ganguly et al., 2010). Keinginan untuk berperilaku dalam pembelian yang didasari oleh sebuah kepercayaan akan mendorong konsumen untuk lebih aktif dalam mencari dan mengevaluasi informasi yang berkaitan dengan rencana pembelian tersebut.

Penelitian ini mempunyai tujuan untuk mengetahui apakah word of mouth berpengaruh terhadap kepercayaan konsumen dalam berbelanja secara online melalui berbagai marketplace yang ada di Indonesia. Menurut iPrice (2018) pada kuartal pertama tahun 2021 terdapat beberapa marketplace di Indonesia yang paling sering dikunjungi yaitu Tokopedia, Shopee, Bukalapak, Lazada dan Blibli.

\section{Rumusan Masalah}

Rumusan masalah yang dapat ditarik berdasarkan latar belakang yang telah diuraikan sebelumnya adalah apakah word of mouth berpengaruh terhadap kepercayaan konsumen dalam berbelanja secara online melalui berbagai marketplace yang ada di Indonesia.

Word of mouth dapat didefinisikan sebagai salah satu faktor yang penting dalam penentuan sikap, pemikiran dan perilaku konsumen terhadap suatu produk atau jasa. Perilaku konsumen yang terbentuk dari word of mouth dipercaya memiliki kekuatan dalam meningkatkan kepuasan dan kepercayaan konsumen. Beberapa penelitian empiris menemukan bahwa word of mouth berpengaruh terhadap kepercayaan konsumen, seperti hasil penelitian dari Abubakar dan Ilkan (2016) dan Wu (2017) yang menyatakan bahwa secara positif berita yang disampaikan secara online melalui word of mouth dapat memengaruhi kepercayaan konsumen. Dari beberapa hasil penelitian terdahulu tersebut maka dapat dirumuskan hipotesis sebagai berikut.

$\mathrm{H}_{1}$ : Pengaruh Word of Mouth terhadap Kepercayaan Konsumen

\section{METODE PENELITIAN}

Metode yang digunakan untuk mengambil sampel dalam penelitian ini adalah dengan menggunakan metode nonprobability sampling dengan teknik purposive sampling sedangkan sampel dalam penelitian ini adalah masyarakat di Kota Bandung yang secara aktif mengunjungi marketplace dan melakukan pembelian minimal 2 kali dalam sebulan. Jumlah sampel yang digunakan adalah sebanyak 100 responden. Teknik analisis data yang digunakan adalah melalui analisis regresi dimana pengujian dilakukan terhadap satu variabel bebas (independen) yaitu 
word of mouth dan satu variabel terikat (dependen) yaitu kepercayaan. Variabel word of mouth diukur melalui 8 butir instrumen pernyataan dengan penggunaan rentang skala likert yaitu 1 untuk "sangat tidak setuju", 2 untuk "tidak setuju", 3 untuk "netral", 4 untuk "setuju" dan 5 untuk "sangat setuju" serta keseluruhan instrumen dari word of mouth merupakan adaptasi dari penelitian Goyette et al. (2010) sedangkan variabel kepercayaan diukur melalui 4 butir instrumen pernyataan dengan penggunaan rentang skala likert yaitu 1 untuk "sangat tidak setuju", 2 untuk "tidak setuju", 3 untuk "netral", 4 untuk "setuju" dan 5 untuk "sangat setuju" serta keseluruhan instrumen dari kepercayaan merupakan adaptasi dari penelitian Oliviera et al. (2017). Pengambilan data dilakukan secara daring melalui aplikasi Google Forms dan selanjutnya diolah dengan menggunakan software SPSS versi 22.

\section{HASIL DAN PEMBAHASAN}

Hasil yang diperoleh dari pengumpulan data terhadap 100 responden dapat digambarkan karakteristik responden sebagai berikut.

Tabel 1. Karakteristik Responden berdasarkan Jenis Kelamin

Sumber: pengolahan data (2021)

\begin{tabular}{cccc}
\hline No & Jenis Kelamin & Total & Persen \\
\hline 1 & Pria & 11 & $11 \%$ \\
\hline 2 & Wanita & 89 & $89 \%$
\end{tabular}

Tabel 1 menunjukkan bahwa wanita merupakan responden dengan jumlah terbanyak yaitu 89 orang. Hal ini disebabkan karena responden wanita dianggap lebih mudah untuk menerima dan menyampaikan word of mouth serta sejalan dengan penelitian yang telah dilakukan oleh Bae dan Lee (2010) dimana menunjukkan bahwa wanita lebih mudah untuk dipengaruhi oleh word of mouth ketika berbelanja secara online dibandingkan pria.

Tabel 2. Karakteristik Responden berdasarkan Usia Sumber: pengolahan data (2021)

\begin{tabular}{llll}
\hline No & Usia & Total & Persen \\
\hline 1 & Dibawah atau sama dengan 20 tahun & 25 & $25 \%$ \\
\hline 2 & $21-30$ tahun & 39 & $39 \%$ \\
\hline 3 & $31-40$ tahun & 23 & $23 \%$ \\
\hline 4 & $41-50$ tahun & 11 & $11 \%$ \\
\hline 5 & Diatas 50 tahun & 2 & $2 \%$ \\
\hline
\end{tabular}

Tabel 2 menunjukkan bahwa responden dengan rentang usia 21 hingga 30 tahun merupakan responden dengan jumlah terbanyak. Hal ini dapat disebabkan bahwa rentang usia 21 hingga 30 tahun dianggap merupakan usia yang cukup aktif dalam berkomunikasi, mampu menerima dan memilah informasi dengan baik serta mampu mengambil keputusan secara mandiri sedangkan responden dengan usia diatas 50 tahun adalah responden yang mempunyai jumlah terendah. Hal ini dapat disebabkan bahwa rentang usia di atas 50 tahun lebih cenderung lebih jarang untuk melakukan komunikasi dengan pihak luar, jarang melakukan melakukan pembelian secara langsung serta lebih memilih untuk menyerahkan segala keputusan pada anggota keluarga yang lebih muda. 
Tabel 3. Karakteristik Responden berdasarkan Kunjungan dan Pembelian Sumber: pengolahan data (2021)

\begin{tabular}{llll}
\hline No & Marketplace & Total & Persen \\
\hline 1 & Tokopedia & 24 & $24 \%$ \\
\hline 2 & Shopee & 46 & $46 \%$ \\
\hline 3 & Bukalapak & 12 & $12 \%$ \\
\hline 4 & Lazada & 9 & $9 \%$ \\
\hline 5 & Bibli & 7 & $7 \%$ \\
\hline $\mathbf{6}$ & $\begin{array}{l}\text { Lainnya: } \\
\text { - Zalora }\end{array}$ & 2 & $2 \%$ \\
\hline
\end{tabular}

Tabel 3 menunjukkan bahwa berdasarkan kunjungan dan pembelian maka Shopee berada pada urutan teratas. Hal ini dapat disebabkan karena karakteristik responden terbanyak dalam penelitian ini adalah wanita dimana menurut beberapa riset dikatakan bahwa wanita memang cenderung lebih menyukai shopee dibandingkan marketplace lainnya. Hal ini mungkin terkait pada harga, fitur, promosi serta keragaman produk yang ditawarkan oleh Shopee.

Hipotesis dalam penelitian ini diuji melalui analisis regresi sederhana dimana dari pengolahan data diperoleh hasil sebagai berikut.

Tabel 4. Coefficients

Sumber: pengolahan data (2021)

\begin{tabular}{|c|c|c|c|c|c|c|}
\hline \multirow[b]{2}{*}{ Model } & & \multicolumn{2}{|c|}{ Unstandardized Coefficients } & \multirow{2}{*}{$\begin{array}{c}\text { Standardized } \\
\text { Coefficients } \\
\text { Beta }\end{array}$} & \multirow[b]{2}{*}{$t$} & \multirow[b]{2}{*}{ Sig. } \\
\hline & & $\mathrm{B}$ & Std. Error & & & \\
\hline 1 & (Constant) & 1.193 & .401 & & 2.976 & .004 \\
\hline & $\begin{array}{l}\text { Word of } \\
\text { Mouth }\end{array}$ & .648 & .110 & .513 & 5.914 & .000 \\
\hline
\end{tabular}

a. Dependent Variable: Kepercayaan

Tabel 5. Model Summary

Sumber: pengolahan data (2021)

\begin{tabular}{cc|c|c|c} 
Model & $\mathrm{R}$ & $\mathrm{R}$ Square & $\begin{array}{c}\text { Adjusted R } \\
\text { Square }\end{array}$ & $\begin{array}{c}\text { Std. Error of the } \\
\text { Estimate }\end{array}$ \\
\hline 1 & $.513^{\mathrm{a}}$ & .263 & .256 & .47960 \\
\hline \multicolumn{4}{c}{$\begin{array}{c}\text { a. Predictors: (Constant), Word of Mouth } \\
\text { b. Dependent Variable: Kepercayaan }\end{array}$}
\end{tabular}

Tabel 4 menunjukkan nilai probabilitas atau sig. adalah sebesar 0.000 , dimana nilai sig. 0,000< 0,05 hal ini menujukkan $\mathrm{H}_{0}$ ditolak yang berarti bahwa word of mouth mempunyai pengaruh terhadap kepercayaan konsumen. Adapun word of mouth berpengaruh terhadap kepercayaan konsumen terlihat pada Tabel 5 yaitu sebesar 0,263 atau 26,3 persen yang berarti sisanya sebesar 73,7 persen dipengaruhi faktor diluar variabel yang diteliti.

Besar pengaruh word of mouth terhadap kepercayaan konsumen sebesar 0,263 atau 26,3 persen menunjukkan bahwa variabel word of mouth tidak terlalu dominan dalam memengaruhi kepercayaan dari konsumen dalam berbelanja online pada marketplace. Rendahnya besar pengaruh word of mouth terhadap kepercayaan konsumen dapat disebabkan dari beberapa faktor antara lain adalah faktor demografis. Karakteristik responden menunjukkan bahwa konsumen yang rutin dalam mengunjungi dan membeli secara online pada marketplace sebagian besar adalah wanita. Hal ini sejalan dengan hasil beberapa riset yang menunjukkan bahwa wanita 
cenderung lebih sering melakukan pembelian secara online pada marketplace dibandingkan pria dimana wanita lebih bersedia meluangkan waktunya untuk mencari produk yang diinginkan namun harga yang lebih rendah, promosi yang lebih banyak sehingga word of mouth bukan menjadi faktor utama yang menjadi pertimbangan dalam membentuk kepercayaan. Karakteristik responden juga menunjukkan bahwa rentang usia terbanyak adalah 21 hingga 30 tahun dimana responden dengan rentang usia tersebut biasanya telah memiliki pemikiran dan perilaku kedewasaan sehingga akan ada lebih banyak pertimbangan dalam membentuk kepercayaan konsumen dalam berbelanja online pada marketplace. Selain daripada faktor demografis, kecepatan layanan, keamanan dalam bertransaksi, keragamaan produk, jaminan, harga dan promosi penjualan yang ditawarkan dapat menjadi faktor utama lainnya yang mendorong konsumen untuk memiliki kepercayaan dalam berbelanja online pada suatu marketplace.

\section{KESIMPULAN DAN SARAN}

Penelitian ini mempunyai tujuan untuk mengetahui karakteristik responden berdasarkan jenis kelamin, usia, marketplace yang paling sering dikunjungi dan melakukan pembelian serta untuk mengetahui apakah word of mouth berpengaruh terhadap kepercayaan konsumen dalam berbelanja secara online.

Saran dalam penelitian ini mengacu pada hasil yang diperoleh dimana word of mouth memberikan pengaruh yang cukup rendah terhadap kepercayaan konsumen sehingga dalam hal ini sebaiknya selain mengandalkan word of mouth yang biasanya diperoleh melalui ulasan atau rating yang diberikan para pembeli, marketplace dapat lebih mengembangkan berbagai strategi pemasaran yang dapat lebih menarik konsumen untuk berbelanja secara online. Strategi yang dapat dikembangkan dapat berupa peningkatan kinerja baik kinerja produk, layanan, harga serta bebagai penawaran promosi yang menarik.

\section{REFERENSI}

Abubakar, AM. \& Ilkan, M. (2016). "Impact of Online WOM on Destination Trust and Intention to Travel: A Medical Tourism Perspective". Journal of Destination Marketing and Management, 5 (3), 192-201. https://doi.org/10.1016/j.jdmm.2015.12.005.

Bae, S. \& Lee, T. (2010). "Gender Differences in Consumers' Perception of Online Consumer Reviews”. Electronic Commerce Research, 11(2), 201-214. DOI:10.1007/s10660-0109072-y.

Ganguly, B., Dash, SB., Cyr, D., Head, M. (2010). "The effects of website design on purchase intention in online shopping: The mediating role of trust and the moderating role of culture". International Journal of Electronic Business, 8(4/5), 302-330. DOI: 10.1504/IJEB.2010.035289.

Giese, JL. \& Cote, JA. (2002). "Defining Consumer Satisfaction". Academy of Marketing Science Review, Vol. 2000 (1). http://www.amsreview.org/articles/giese01-2000.pdf

Goyette, I., Ricard, L., Bergeron, J., Marticotte, F. (2010). "e-WOM Scale: Word-of-Mouth Measurement Scale for e-Services Context". Canadian Journal of Administrative Sciences 27: 5-23. Published online in Wiley Interscience (www.interscience.wiley.com). DOI: 10.1002/CJAS.129.

IPrice. (2018). Peta e-commerce Indonesia. Diambil 20 Agustus 2021 dari https://iprice.co.id/insights/mapofecommerce/.

Kotler, P. \& Keller, KL. (2013). Manajemen Pemasaran Edisi 13 Jilid 2. Penerbit Erlangga. 
Norhermaya, YA. \& Soesanto, H. (2016). “Analisis Pengaruh Kepuasan Pelanggan Terhadap Kepercayaan Dan Loyalitas Pelanggan Untuk Meningkatkan Minat Beli Ulang (Studi Pada Online Store Lazada.Co. Id)". Diponegoro Journal of Management, 5(3), 1-13.

Oliviera, T., Alhinho, M., Rita, P., Dhillon, G. (2017). "Modelling and Testing Consumer Trust Dimensions in E-Commerce". Computer in Human Behavior, 71(June). 153-164. https://doi.org/10.1016/j.chb.2017.01.050.

Peter, JP. \& Olson, JC. (2010). Consumer Behavior \& Marketing Startegy $9^{\text {th }}$ ed. McGrawa-Hill/ Irwin.

Toruan, RRML. (2018). "Proses Implementasi Word ff Mouth dalam Strategi Komunikasi Pemasaran La Perla Plaza Senayan”. Jurnal Pustaka Komunikasi, Vol. 1, No. 1, 155 - 166.

Wu, MSF. (2017). "A Study on the Effects of Word-of-Mouth on Brand Trust in Tourism Industry”. EURASIA Journal of Mathematics, Science and Technology Education, 13(12), 7995-8002. DOI: 10.12973/ejmste/77904. 